\title{
ЦИФРОВА КОМПЕТЕНТНІСТЬ МАЙБУТНЬОГО ФАХІВЦЯ ФІЛОЛОГІЧНОГО ТА ПРИРОДНИЧОГО ПРОФІЛЮ
}

\author{
С. О. Доценко, Т. М. Собченко
}

\author{
DIGITAL COMPETENCE OF THE FUTURE SPECIALIST \\ IN HUMANITIES AND NATURAL SCIENCES
}

\author{
S. Dotsenko, T. Sobchenko
}

\begin{abstract}
Визначено дидактичний та освітній потенціал змістового модуля «Засоби цифрової підготовки» навчальної дисципліни «Педагогіка» для розвитку цифрових компетентностей студентів гуманітарних та природничих спеціальностей. Індекс цифрової компетентності у двох групах $\Gamma_{1}$ (природничий факультет) та Г⿸厂二 факультет) було визначено за допомогою вхідної та підсумкової діагностики, які розроблені згідно з рамкою цифрової компетентності DigComp 2.0 та методикою «Індекс цифрової компетентності» (Г. Солдатова та інші). Про ефективність зазначеного змістового модуля та його суттєвий вплив на розвиток цифрової компетентності студентів свідчать отримані результати: на рівні А1 (Початківець. Потрібно розвивати цифрові навички) - 14,3\% студентів групи $\Gamma_{1}$, та 10,5\% групи $\Gamma_{2}$; на рівні А2 (Дослідник. Розуміє високий потенціал цифрових технологій, але ситуативно використовує цифрові інструменти для навчання) - 17,1\% студентів групи $\Gamma_{1}$, та $10,5 \%$ групи $\Gamma_{2}$; на рівні В1 (Інтегратор. Експериментує з цифровими інструментами в різних контекстах, інтегрує їх у своїй навчальній діяльності) - 20,1\% $\Gamma_{1}$ та 23,7\% $\Gamma_{2}$ ), на рівні В2 (Експерт. Цілеспрямовано добирає цифрові інструменти для певної ситуації) - 14,3\% $\Gamma_{1}$ та 21,1\% $\Gamma_{2}$. На рівні С1 (Лідер. Володіє певним набором цифрових інструментів та знає, як обрати найбільш ефективний у певній ситуації) $-17,1 \%$ в групі $\Gamma_{1}$ та $15,8 \%$ в групі $\Gamma_{2}$. На рівні C2 (Новатор. Експериментує з високо інноваційними цифровими технологіями та розробляє свої) $-17,1 \%$ в групі $\Gamma_{1}$ та $18,4 \%$ в групі $\Gamma_{2}$. Результати моніторингових досліджень дають всі підстави стверджувати, що розроблений змістовий модуль «Засоби цифрової підготовки» як складова навчальної дисципліни «Педагогіка» сприяє підвищенню рівня сформованості цифрової компетентності студентів. При цьому бачимо суттєвіші відмінності між показниками студентів гуманітарних та природничих спеціальностей, що свідчить про те, що для гуманітаріїв потрібно збільшити кількість годин на вивчення зазначеного модуля або впровадити нову навчальну дисципліну.

Ключові слова: цифрова компетентність, педагогіка, моніторинг, цифрові технології, цифрові інструменти, Інтернет.

It was determined the didactic and educational potential of the content module "Means of digital training" of the discipline "Pedagogy" for the development of digital competencies of students of humanities and natural sciences. The digital competence index in two groups: G1 (Faculty of Natural Sciences) and G2 (Faculty of Humanities) was determined using input and
\end{abstract}


final diagnostics, which were developed according to the digital competence framework 0DigComp 2.0. and the method of "Index of digital competence" (G. Soldatova and others). The effectiveness of this content module and the significant impact on the development of digital competence of students show the results: at the level of A1 (Beginner. Need to develop digital skills) $-14.3 \%$ of students in group G1, and $10.5 \%$ in group G2; at the A2 level (Researcher. Understands the high potential of digital technologies, but single-handedly uses digital tools for learning) $-17.1 \%$ of students in group G1, and 10.5\% of group G2; at B 1 level (Integrator. Experiments with digital tools in different contexts, integrates them in their educational activities) - 20.1\% (G1) and 23.7\% (G2), at level B2 (Expert. Purposefully selects digital tools for particular situations) $-14.3 \%(\mathrm{G} 1)$ and $21.1 \%(\mathrm{G} 2)$. C1 level (Leader. Has a certain set of digital tools and knows how to choose the most effective in a given situation) $17.1 \%$ in group G1 and $15.8 \%$ in group G2. At C2 level (Innovator. Experiments with highly innovative digital technologies and develops its own) $-18.4 \%$ in G1 group and $17.1 \%$ G2 group. The monitoring results confirm that the developed content of module "Digital Training Tools" as part of the discipline "Pedagogy" increases the digital competence level of students. At the same time, there are more significant differences between the indicators of students of humanities and natural sciences, which indicate that the humanities need to increase the number of hours to study this module or introduce a new discipline.

Keywords: digital competence, pedagogy, monitoring, digital technologies, digital tools, Internet.

Постановка проблеми. Динамічні зміни, що відбуваються в сучасному інформаційному суспільстві, суттєво впливають на ринок праці, який визначає нові вимоги до створення кластера компетентностей, якими має володіти молодий спеціаліст. Міждисциплінарність, інтеграція та синергія стають реальністю сучасної освіти. Цифровізація всіх сфер життя, зокрема й системи освіти, спричинює нові вимоги до рівня сформованості цифрової компетентності кожного громадянина. Постійне вдосконалення цифрових технологій, з одного боку, та стрімка цифрова трансформація сучасного суспільства, 3 другого, стають останнім часом основними чинниками модернізації вищої освіти - ії змісту, методології, форм, методів, технологій.

Щоб відповісти на виклики сучасності, вища освіта трансформує навчальні програми, розробляючи спеціальні модулі та впроваджуючи інтерактивні методи навчання, що забезпечують синергію універсальних компетентностей та цифровізацію навчання.

Ключові компетентності та базові навички грамотності, на думку вчених і фахівців освітньої галузі, мають бути сформовані вже до вступу до вишу, в процесі навчання у школі. Однак, по-перше, життєво важливі компетентності можуть втрачатися, змінюватися або набуватися протягом усього життя, оскільки змінюються економічні, технологічні та соціальні 
умови буття людини. По-друге, практика викладання у ЗВО свідчить про наявність суттєвих пробілів у цифрових компетентостях студентів, що іноді навіть стають перешкодою для успішного навчання у виші.

Аналіз основних досліджень і публікацій, в яких започатковано розв'язання даної проблеми. Нормативною базою дослідження для з'ясування можливостей i умов формування цифрової компетентності студентів є документи Міністерства освіти та науки і чинне законодавство України про вищу освіту: (Закон України «Про вищу освіту» (зі змінами 2017 р.), Закон України «Про національну програму інформатизації» (1998, зі змінами 2015 р.) та інші.

Аналіз психолого-педагогічної літератури (Маркова, Семеріков, \& Стрюк, 2015; Морзе та ін., 2019; Семеріков, Стрюк, \& Моісеєнко, 2012) свідчить, що існують різні визначення поняття «цифрова компетентність», оскільки його значущість, статус, зміст постійно змінюються відповідно до потреб часу. Більшість авторів включають в поняття «цифрова компетентність» здатності та навички ефективно використовувати цифрові технології у повсякденному житті; здатності та навички критично оцінювати інформацію, мотивацію до участі у розбудові цифрової культури та технічні навички, пов'язані із комп'ютерною грамотністю.

Існує чимало визначень цифрової компетентності. Ми згодні 3 розробниками Опису цифрової компетентності педагогічного працівника (Морзе та ін., 2019), що цифрову компетентність педагогічного працівника можна визначити як «складне динамічне цілісне інтегративне творення особистості, яке $\epsilon$ його багаторівневою професійно-особистісною характеристикою в сфері цифрових технологій i досвіду їхнього використання, що обумовлене 3 одного боку потребами та вимогами цифрового суспільства, а з іншого появою цифрового освітнього простору, який змінює освітню (навчально-виховну) взаємодію всіх іiі учасників» (c. 50). Г. Генсерук (2019) цифрову компетнтність визначає як одну із професійно значущих компетентностей майбутніх учителів; Г. Солдатова й О. Рассказова (2014) - як «суму загально користувацьких і професійних знань і вмінь, які представлені в різних моделях ІКТ-компетентностей, та установку на ефективну діяльність і особисте ставлення до неї, засноване на почутті відповідальності».

Європейським Парламентом та Радою Європейського Союзу у 2006 р. цифрова компетентність визначена як одна із ключових для навчання впродовж життя. Об'єднаним дослідницьким центром Єврокомісії та 
Генеральною дирекцією з питань освіти, молоді, спорту та культури разом 3 групою експертів зі всієї Свропи розроблено та реалізовано проєкт SELFIE - Self-reflection on Effective Learning by Fostering the Use of Innovative Educational Technologies (European Commission, 2019). Проєкт $\epsilon$ частиною представленого Сврокомісією «Плану дій у цифровій освіті», в якому головним завданням визначено залучення до 2019 p. мільйона користувачів, зокрема керівників шкіл, учителів, учнів із країн-учасників ЄC. SELFIE - це інструмент, який допомагає школам впроваджувати цифрові технології у навчальний процес. За його допомогою можна визначити, що працює ефективно, де необхідна допомога та які потрібно визначити пріоритети.

У рамках SELFIE анонімно збираються думки учнів, вчителів та керівництва школи щодо використання цифрових технологій в освітніх закладах. Учасникам пропонуються короткі твердження та питання 3 простою шкалою відповідей від 1 до 5. Ці питання охоплюють такі сфери як лідерство, інфраструктура, підвищення кваліфікації вчителів та здатність учнів використовувати цифрові технології (European Commission, 2019).

Питання використання потенціалу цифрових технологій для суспільного зростання добробуту, впровадження побудованої на цифровій основі інноваційної освіти та новітніх практик навчання, покращення доступу до навчання протягом усього життя, а також розвитку цифрових навичок та компетентностей, необхідних в сучасних умовах для працевлаштування, розвитку особистості та соціальної інклюзії почали активно досліджуватися на загальноєвропейському рівні з 2005 р. 3 цих питань було проведено більше 20 широкомасштабних досліджень, на матеріалах яких виконано понад 100 різних публікацій.

У 2013 р. побачила світ Європейська система цифрової компетентності в Свропі, також відома як DigComp (Ferrari, 2013). У 2016 р. Європейською комісією було запроваджено Рамку цифрової компетентності для громадян - DigComp 2.0: The Digital Competence Framework for Citizens (Vuorikari, Punie, Carretero Gomez, \& Van den Brande, 2016). Уже наступного, 2017 р. з'явилася DigComp 2.1 (Carretero Gomez, Vuorikari \& Punie, 2017), яка зробила крок від початкових трьох рівнів цифрових кваліфікацій до більш детального опису восьми рівнів.

Як зазначають автори (Carretero Gomez et al., 2107), 8 рівнів кваліфікації для кожної компетентності були визначені в термінах результатів навчання 3 використанням дієслів за таксономією цілей 
навчання Б. Блума та структуровані за зразком Європейської рамки кваліфікацій. Опис кожного рівня кваліфікації містить конкретизовану характеристику знань, умінь і ставлень; загалом наведено 168 дескрипторів (21 результат навчання х 8 рівнів) (с. 12).

Шляхи адаптації рамки цифрової компетентності для вітчизняної освіти досліджувала О. Овчарук, яка зазначила, що «DigComp є загальною еталонною моделлю для європейських країн з метою створення спільної мови 3 розвитку цифрових компетентностей. Вона вкрай важлива і для вітчизняних освітян (Овчарук, 2017).

У вересні 2017 р. комісією Broadband Commission for Sustainable Development за ініціативою ЮНЕСКО та Intel опубліковано звіт щодо сталого розвитку «Цифрові навички для життя та роботи». Звіт констатував наявність проблеми нерівності в набутті цифрових компетентностей, зокрема цифрових навичок, за статевими, соціальними, географічними та віковими принципами. У документі запропоновано стратегії, які сприятимуть набуттю цифрових навичок представниками всіх груп населення (Broadband Commission for Sustainable Development, 2017).

У звіті подано три групи необхідних цифрових навичок i компетентностей, а саме:

1) базові функціональні навички (вміння працювати 3 пристроями, заходити в Інтернет, створювати обліковий запис, знаходити інформацію або необхідний ресурс в мережі, а також дрібну моторику (навик друкування на клавіатурі) та жести (уміння роботи із сенсорними екранами);

2) стандартні цифрові навички (навички використання цифрових технологій; уміння оцінювати інтернет-джерела та релевантність отриманих даних, зберігати та організовувати отриману інформацію; здатність захищати наявні пристрої та отриману інформацію від вірусів і інтернетатак; дотримання авторських прав та уникнення плагіату);

3) просунуті навички (професійні навички, зокрема вміння програмувати, розробляти програми, адмініструвати мережі, аналізувати дані; «навички XXI століття»: вміння працювати в команді, нетворкінг, критичне мислення, творчий підхід, креативність, підприємливість) (c. 22-36).

Особливої уваги у звіті надається додатковим цифровим навичкам, а саме: розуміння принципів конфіденційності; знання основ поведінки відповідального цифрового громадянина тощо (Broadband Commission for Sustainable Development, 2017). 
Теоретичні аспекти розвитку сучасного інформаційнокомунікаційного педагогічного середовища, зокрема активне впровадження цифрових технологій, що призводить до оновлення понятійного апарату, введення до наукового обігу категорій «цифрової культури», «цифрової грамотності» розглядали Л. Гаврілова та Н. Воронова (2017).

Метою статті $\epsilon$ виявлення впливу змістового модуля «Засоби цифрової підготовки» курсу педагогіки на розвиток цифрової компетентності студентів гуманітарних та природничих спеціальностей.

Виклад основного матеріалу. У своїй практичній діяльності ми зіткнулися 3 тим, що у багатьох студентів першого курсу виникають проблеми при підготовці презентацій, інфографіки, відеоматеріалів. Вони не вміють користуватися програмами на планшетах і комп'ютерах, проєкторами, інтерактивними дошками. Тому при підготовці сучасного педагога важливо формувати у студентів цифрові компетентності під час вивчення певних навчальних дисциплін.

Для вирішення поставлених завдань та перевірки вихідних припущень ми користувалися комплексом науково-дослідних методів: спостереження, онлайн-моніторинг, порівняльний аналіз та синтез. Так, під час вивчення одного зі змістових модулів «Засоби цифрової підготовки» навчальної дисципліни «Педагогіка» студенти 1 курсу проходили вхідне анкетуваня, методику якого було розроблено з орієнтацію на цифрові компетентності, визначені проєктом European Digital Competence Framework. Метою анкетування було порівняння рівнів сформованості цифрових компетентностей студентів гуманітарних та природничих факультетів перед вивченням зазначеного модуля. В анкетуванні взяли участь студенти ХНПУ імені Г. С. Сковороди: природничого факультету (група $\Gamma_{1}-35$ студентів) та українського мовно-літературного факультету імені Г. Ф. КвіткиОснов'яненка (група $\Gamma_{2}-38$ студентів). Результати анкетування наведено в таблиці 1.

Таблиия 1

Результати анкетування студентів

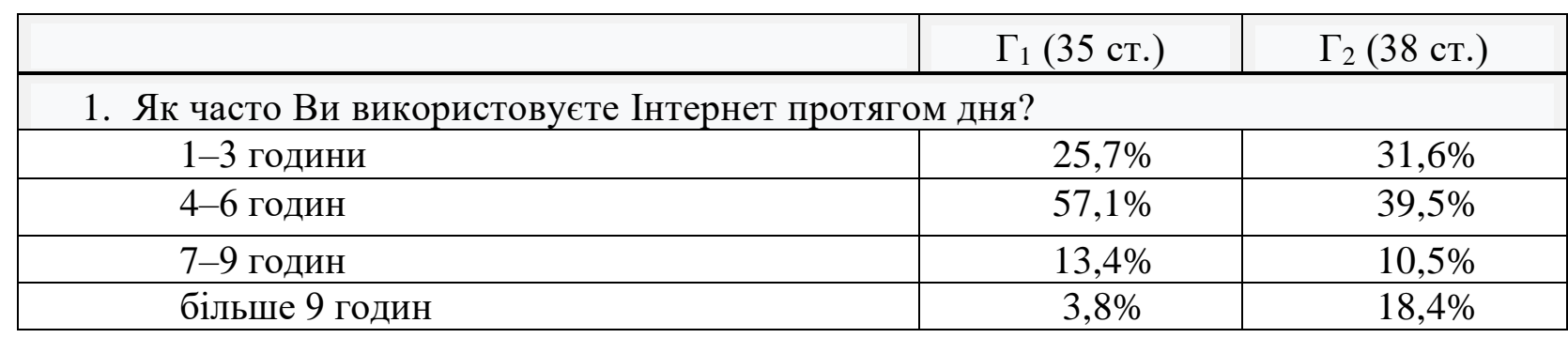


Продовження таблищу 1

\begin{tabular}{|c|c|c|}
\hline & $\Gamma_{1}(35$ ст.) & $\Gamma_{2}(38 \mathrm{cт})$. \\
\hline \multicolumn{3}{|c|}{ 2. Який пристрій Ви використовуєте найчастіше для користування Інтернет? } \\
\hline мобільний телефон/смартфон & $60,0 \%$ & $44,7 \%$ \\
\hline ноутбук & $22,9 \%$ & $28,9 \%$ \\
\hline стаціонарний комп’ютер & $17,1 \%$ & $26,3 \%$ \\
\hline \multicolumn{3}{|c|}{ 3. 3 якою метою Ви використовуєте Інтернет? } \\
\hline пошук інформації & $17,1 \%$ & $10,5 \%$ \\
\hline підготовка до занять & $11,4 \%$ & $7,9 \%$ \\
\hline ігри & $14,3 \%$ & $21,1 \%$ \\
\hline соціальні мережі & $28,6 \%$ & $39,5 \%$ \\
\hline для роботи & $8,6 \%$ & $0 \%$ \\
\hline для спілкування & $20,0 \%$ & $18,4 \%$ \\
\hline інше & $0 \%$ & $2,6 \%$ \\
\hline \multicolumn{3}{|l|}{ 4. Які сайти Ви відвідуєте найчастіше? } \\
\hline навчальні & $14,2 \%$ & $21,1 \%$ \\
\hline розважальні & $42,9 \%$ & $42,1 \%$ \\
\hline віртуального спілкування & $42,9 \%$ & $36,8 \%$ \\
\hline \multicolumn{3}{|c|}{ 5. 3 якими програмами/платформами Ви вмієте працювати, або бажали б навчитися } \\
\hline \multicolumn{3}{|c|}{ працювати? } \\
\hline Microsoft Word & $14,3 \%$ & $28,9 \%$ \\
\hline Microsoft PowerPoint & $20,0 \%$ & $23,7 \%$ \\
\hline Microsoft Excel & $5,7 \%$ & $7,9 \%$ \\
\hline Photoshop & $2,9 \%$ & $0 \%$ \\
\hline Canva & $25,7 \%$ & $18,4 \%$ \\
\hline MovieMaker & $31,4 \%$ & $21,1 \%$ \\
\hline \multicolumn{3}{|c|}{ 6. Як часто Ви користуєтеся або переглядаєте електронну пошту? } \\
\hline кілька разів на день & $20,0 \%$ & $15,8 \%$ \\
\hline один раз на тиждень & $17,4 \%$ & $34,2 \%$ \\
\hline один раз на день & $34,3 \%$ & $21,1 \%$ \\
\hline раз на місяць & $28,3 \%$ & $26,1 \%$ \\
\hline інше & $0 \%$ & $2,8 \%$ \\
\hline \multicolumn{3}{|c|}{ 7. Чи використовуєте Ви сервіси Google? } \\
\hline так & $85,7 \%$ & $81,6 \%$ \\
\hline ні & $14,3 \%$ & $13,2 \%$ \\
\hline Не знаю таких сервісів & $0 \%$ & $5,2 \%$ \\
\hline \multicolumn{3}{|c|}{ 8. Чи є у Вас власний сайт, чи блог, чи ютуб-канал? } \\
\hline$\epsilon$ сайт & $2,9 \%$ & $5,3 \%$ \\
\hline є блог & $5,7 \%$ & $0 \%$ \\
\hline є ютуб-канал & $11,5 \%$ & $10,5 \%$ \\
\hline є і сайт, і блог, і ютуб-канал & $2,9 \%$ & $0 \%$ \\
\hline немає & $77,0 \%$ & $84,2 \%$ \\
\hline
\end{tabular}


Найчастіше використовують розважальні сайти та сайти віртуального спілкування студенти групи $\Gamma_{1}$ (по 42,9\%). Студенти групи $\Gamma_{2}$ понад усе відвідують розважальні сайти $(42,1 \%)$. Це свідчить, що студенти не достатньо обізнані та не повною мірою усвідомлюють можливості навчальних сайтів і не використовують їх під час підготовки до занять.

На питання «3 якими програмами/платформами ви вмієте працювати, або бажали б навчитися?» 25,7\% студентів групи $\Gamma_{1}$ обрали Canva, a 28,9\% студентів групи $\Gamma_{2}$ обрали Microsoft Word.

Частіше переглядають пошту студенти природничого факультету (34,3\% - один раз на день), один раз на тиждень - студенти гуманітарного факультету (34,2\%). Це свідчить, що електронною поштою більше користуються студенти природничих спеціальностей.

Сервіси Google використовують 85,7\% студентів групи $\Gamma_{1}$ та 81,6\% групи $\Gamma_{2} .77 \%$ групи $\Gamma_{1}$ та 84,2\% групи $\Gamma_{2}$ відповіли, що не мають власного сайту, блогу, чи ютуб-каналу. Лише $11,5 \%$ студентів $\Gamma_{1}$ та $10,5 \%$ студентів $\Gamma_{2}$ зазначили, що у них є ютуб-канал.

Отримані результати дали можливість скоригувати навчальну програму з педагогіки, зокрема змістовий модуль 1 «Засоби цифрової підготовки».

Метою викладання змістового модулю «Засоби цифрової підготовки» $\epsilon$ формування інформаційної та цифрової компетентностей майбутніх учителів, досягнення ними компетентнісного рівня, що відповідає державним та європейським вимогам до IT-компетентностей фахівців педагогічних спеціальностей. Усвідомлення сутності основних понять і теорій інформаційно-комунікаційних технологій щодо подальшого їх використання у педагогічній діяльності, формування здатності усвідомлювати інформаційну педагогічну дійсність, навчити приймати ефективні педагогічні рішення засобами IКТ.

У результаті опанування змісту навчальної дисципліни здобувачі мають досягнути таких програмових результатів навчання: самостійно організовувати процес навчання упродовж життя і вдосконалювати 3 високим рівнем автономності здобуті під час навчання предметні компетентності, вміти спілкуватись у діалоговому режимі з колегами та цільовою аудиторією; володіти інформаційними технологіями в загальній, спеціальній та інклюзивній освіті; володіти навичками роботи 3 комп'ютером на рівні користувача, застосовувати IКТ для розв'язання практичних завдань у галузі професійної діяльності. 
Так, до змісту програми було введено теми: «Мережеві освітні технології», «Єдине інформаційне освітнє середовище», «Візуалізація навчального матеріалу», «Інфографіка як форма наочності (ментальні карти, хмари слів)», «Розробка освітніх мультимедійних ресурсів (аудіо, відео, анімації)», «Мобільне, дистанційне та змішане навчання», «Створення проєктів у Google документах», «Сервіси Web 2.0», «Електронне портфоліо».

До та після вивчення змістового модуля «Засоби цифрові підготовки» на основі ідей Г. Солдатової, О. Рассказової, Т. Нестик та О. Зотової і за методикою «Індекс цифрової компетентності» (Солдатова, Нестик, Рассказова, \& Зотова, 2013; Солдатова, \& Рассказова, 2014) було визначено індекси цифрової компетентності студентів гуманітарних та природничих факультетів.

Слідом за названими дослідниками, виокремлюємо у структурі цифрової компетентності чотири складники: 1) знання, 2) уміння, 3) мотивацію та 4) відповідальність і безпеку (Солдатова та ін., 2013, с. 16-17). Для вимірювання рівня розвитку кожного складника цифрової компетентності та розрахунку на цій основі індексу, кожен учасник експерименту відповідав на низку запитань. Батареї запитань на визначення сформованості знань і мотивації містили по 10 пунктів. На визначення сформованості вмінь - 25 запитань, стосовно відповідальності - 11 запитань (Солдатова та ін., 2013, с. 49-52). Кожна позитивна відповідь (вибір, згода) оцінювалася в 1 бал, негативна - 0 балів. Сума балів за кожним складником цифрової компетентності ділилася на кількість запитань у батареї стосовно цього складника і множилася на 100\%.

На підставі отриманих у такий спосіб балів за кожним складником розраховувався підсумковий інтегрований індекс цифрової компетентності кожного учасника експерименту за формулою (Солдатова та ін., 2013, с. 52):

\section{Індекс цифрової компетентності = $=($ Знання + Уміння + Мотивація + Відповідальність $) / 4$}

Орієнтуючись на влучні формулювання, наведені в Європейській рамці цифрових компетентностей для освітян - European Framework for the Digital Competence of Educators: DigCompEdu (Redecker, 2017), ми визначили 6 рівнів сформованості цифрових компетентностей студентів: A1 - Початківець - потребує розвитку цифрових навичок; А2 - Дослідник - 
розуміє високий потенціал цифрових технологій, але використовує цифрові інструменти для навчання ситуативно; В1 - Інтегратор - експериментує 3 цифровими інструментами в різних контекстах, інтегрує їх у своїй навчальній діяльності; В2 - Експерт - цілеспрямовано добирає цифрові інструменти для певної ситуації; C1 - Лідер - володіє певним набором цифрових інструментів та знає, як обрати найбільш ефективний у певній ситуації; С2 - Новатор - експериментує з високо інноваційними цифровими технологіями та розробляє свої способи їх застосування. На основі обчисленого індексу цифрової компетентності, кожен учасник експерименту був віднесений до однієї із шести перелічених вище груп: 0-17 - A1, 18-35 - A2, 36-53 - B1, 54-71 - B2, 72-89 - C1, 90-100 - C2.

Результати презентовано в таблиці 2.

Таблиия 2

Індекси цифрової компетентності студентів

\begin{tabular}{|c|c|c|c|c|c|c|}
\hline & \multicolumn{3}{|c|}{ Г1 (35 студ.) } & \multicolumn{3}{|c|}{ Г2 (38 студ.) } \\
\hline & 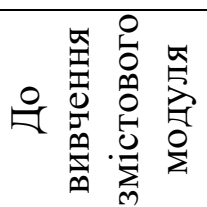 & 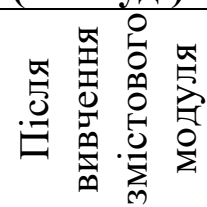 & 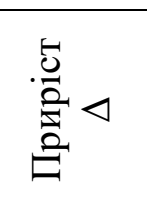 & 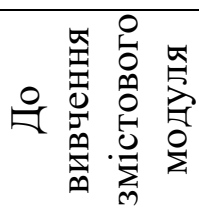 & 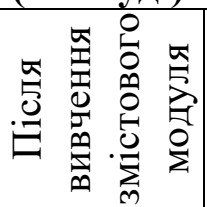 & 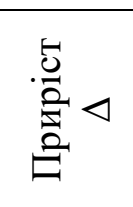 \\
\hline А1 - Початківець & $28,6 \%$ & $14,3 \%$ & $-14,3 \%$ & $26,3 \%$ & $10,5 \%$ & $-15,8 \%$ \\
\hline А2 - Дослідник & $31,4 \%$ & $17,1 \%$ & $-14,3 \%$ & $18,4 \%$ & $10,5 \%$ & $-7,9 \%$ \\
\hline В1 - Інтегратор & $14,3 \%$ & $20,1 \%$ & $+5,8 \%$ & $18,4 \%$ & $23,7 \%$ & $+5,3 \%$ \\
\hline В2 - Експерт & $11,4 \%$ & $14,3 \%$ & $+2,9 \%$ & $15,8 \%$ & $21,1 \%$ & $+5,3 \%$ \\
\hline С1 - Лідер & $8,6 \%$ & $17,1 \%$ & $+8,5 \%$ & $7,9 \%$ & $15,8 \%$ & $+7,9 \%$ \\
\hline C2 - Новатор & $5,7 \%$ & $17,1 \%$ & $+11,4 \%$ & $13,2 \%$ & $18,4 \%$ & $+5,2 \%$ \\
\hline
\end{tabular}

Дані, що були отримані, підтвердили позитивну динаміку індексів цифрової компетентності в обох група. Зокрема, в групі $\Gamma_{1}$ на 11,4\% збільшилася кількість студентів на рівні С2 (новатор) та на 8,5\% - на рівні С1 (лідер). Істотно зменшилася кількість студентів на рівні А1 (початківець) - на 14,3\%. У групі $\Gamma_{2}$ теж відбулись істотні зміни: на 5,2\% збільшилася кількість студентів на рівні С2 (новатор) та удвічі - на рівні С1 (лідер). На $15,8 \%$ зменшилося кількість студентів на початковому рівні А1 та на 7,9\% на рівні А2 (дослідник).

Порівняння змін індексів цифрової компетентності у групах $\Gamma_{1}$ та $\Gamma_{2}$ наведено у вигляді гістограми на рис. 1. 


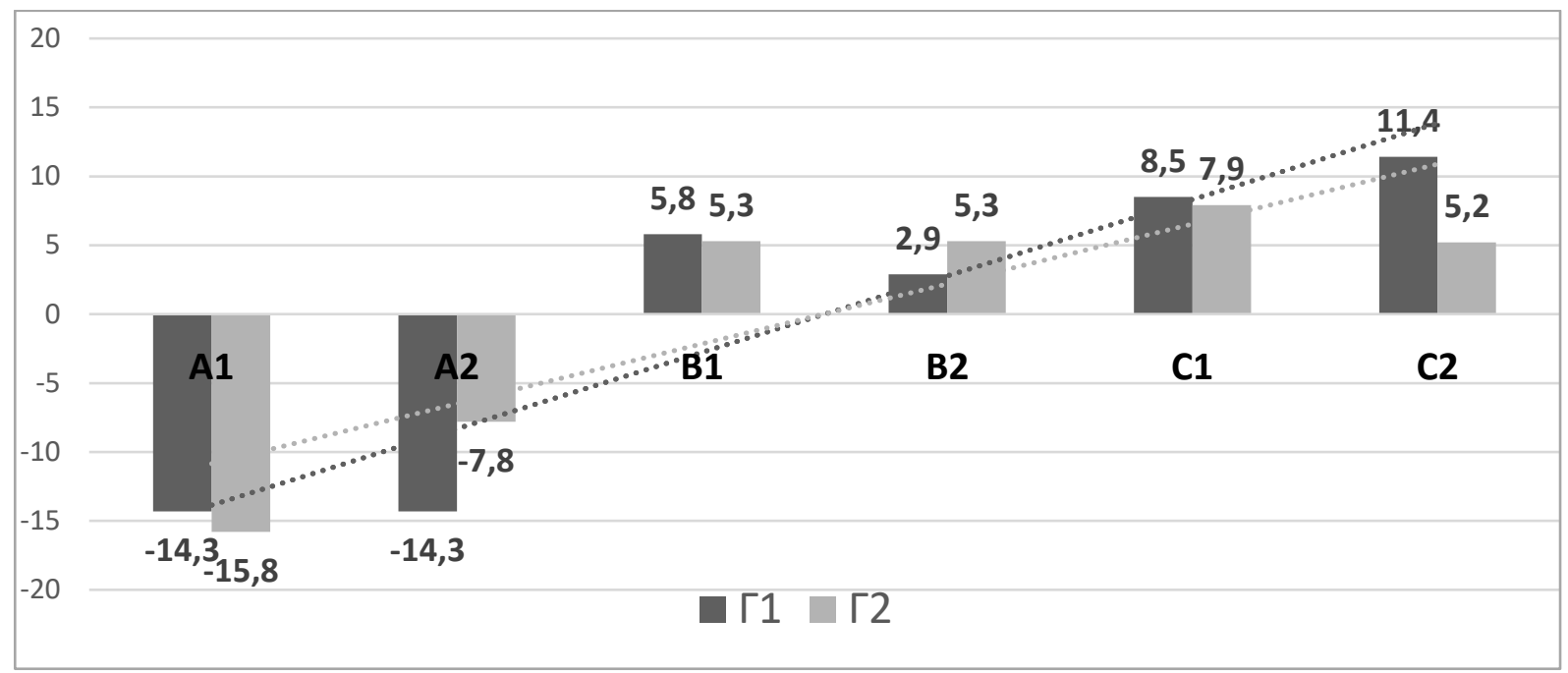

\section{Рис. 1. Зміни індексів цифрової компетентності студентів після вивчення змістового модулю «Засоби цифрової підготовки»}

Отримані дані свідчать про значущі позитивні зміни індексів цифрової компетентності всіх учасників експерименту після вивчення змістового модуля «Засоби цифрової підготовки» курсу педагогіки. Водночас зазначимо, що в групі $\Gamma_{1}$ (природничий факультет) відбулися дещо суттєвіші, порівняно з групою $\Gamma_{2}$ (гуманітарний факультет), зміни. На це вказують, 3-поміж іншого, і пунктирні лінії трендів на гістограмі (темніша $\Gamma_{1}$, світліша $-\Gamma_{2}$ ). Так, у групі $\Gamma_{1}$, порівняно $3 \Gamma_{2}$, удвічі більший приріст числа учасників, які перейшли на рівень С2; також удвічі більше учасників піднялися на вищі щаблі з рівня А2.

При цьому не слід забувати про специфіку природничих i гуманітарних спеціальностей, що потенційно може впливати на взаємини студентів із комп'ютерною технікою і, відповідно, на формування цифрової компетентності. Утім, детальне дослідження наявності/відсутності такої кореляції може стати предметом подальших наукових пошуків.

Висновки і перспективи подальших розвідок. У цілому можна констатувати зростання індексів цифрової компетентності студентів природничих і гуманітарних спеціальностей після вивчення змістового модуля «Засоби цифрової підготовки» курсу педагогіки. Водночас відмінності в інтенсивності позитивних змін між групами природничих i гуманітарних спеціальностей наштовхують на думку про необхідність диференціації змісту модуля, форм і методів навчально-пізнавальної роботи з урахуванням специфіки спеціальностей. 
Також до перспективних гіпотез можемо віднести припущення про вплив специфіки природничих і гуманітарних наук на формування цифрової компетентності студентів, які їх опановують.

Так чи інакше, але бачимо необхідність розробки та експериментальної перевірки нової навчальної дисципліни для студентів гуманітарних спеціальностей зі збільшенням часу на формування цифрових компетентностей та добору спеціальних форм і методів роботи відповідно до специфіки гуманітарних спеціальностей, аби подолати «цифровий розрив», який намітився між студентами-природничниками та гуманітаріями. 


\section{СПИСОК ЛІТЕРАТУРИ}

Гаврілова, Л., \& Воронова, Н. (2017). Цифрова культура як феномен сучасного інформаційно-комунікаційного педагогічного середовища. Засоби навчальної та науково-дослідної роботи, 48, 21-34.

DOI: http://doi.org/10.5281/zenodo.1312912

Генсерук, Г. (2019). Цифрова компетентність як одна із професійно значущих компетентностей майбутніх учителів. Відкрите освітнє е-середовище сучасного університету, 6, 8-16. Отримано 3: http://nbuv.gov.ua/UJRN/oeeemu_2019_6_4

Маркова, О., Семеріков, С., \& Стрюк, А. (2015). Хмарні технології навчання: витоки. Інформаційні технології $i$ засоби навчання, 46(2), 29-44. Отримано 3: http://nbuv.gov.ua/UJRN/ITZN_2015_46_2_6.

Морзе, Н. В., Базелюк, О. В., Воротнікова, І. П., Дементієвська, Н. П., Захар, О. Г., Нанаєва, Т. В. ... Чернікова, Л.А. (2019). Опис цифрової компетентності педагогічного працівника. Відкрите освітне е-середовище сучасного університету, спеціальний випуск. Отримано з: https://elibrary.kubg.edu.ua/id/eprint/27905/1/digital\%20comp\%20teacher\%20Morze. pdf

Овчарук, О. (2017). Сучасні вимоги до цифрової грамотності в системі шкільної освіти: на основі рамки цифрової компетентності DigComp 2.0. Нова педагогічна думка, 4, 32-35. Отримано 3: http://nbuv.gov.ua/UJRN/Npd_2017_4_11

Про вищу освіту. № 1556-VII. (2014). Отримано 3: https://zakon.rada.gov.ua/laws/show/1556-VII\#Text

Про національну програму інформатизації. № 74/98-ВР. (1998). Отримано з: https://zakon.rada.gov.ua/laws/show/74/98-\%D0\%B2\%D1\%80\#Text

Семеріков, С., Стрюк, С., \& Моісеєнко, Н. (2012). Мобільне навчання: історикотехнологічний вимір. У О.А. Коновал (ред.). Теорія $i$ практика організації самостійної роботи студентів вищих навчальних закладів (сс. 188-242). Кривий Ріг: Книжкове видавництво Киреєвського.

Солдатова, Г. У., \& Рассказова, Е. И. (2014). Психологические модели цифровой компетентности российских подростков и родителей. Национальный психологический журнал, 2(14), 27-35. Отримано 3: http://npsyj.ru/articles/detail.php?article=5102

Солдатова, Г. У. Нестик, Т. А., Рассказова, Е. И., \& Зотова, Е. Ю. (2013). Цифровая компетентность подростков и родителей. Получено из: https://ifap.ru/library/book536.pdf

Broadband Commission for Sustainable Development (2017). Working Group on Education: Digital skills for life and work. UNESCO; Intel. Retrieved from: https://d-russia.ru/wpcontent/uploads/2017/10/Digital-skills-for-life-and-work_259013e.pdf

Carretero Gomez, S., Vuorikari, R. \& Punie, Y. (2017). DigComp 2.1: The Digital Competence Framework for Citizens with eight proficiency levels and examples of use. Luxembourg: Publications Office of the European Union.

DOI: http://doi.org/10.2760/38842 
European Commission. (2019). SELFIE (Self-reflection on Effective Learning by Fostering the use of Innovative Educational technologies). Retrieved from: https://ec.europa.eu/education/schools-go-digital/about-selfie_en

Ferrari, A. (2013). DIGCOMP: A Framework for Developing and Understanding Digital Competence in Europe. Y. Punie \& B. N. Brečko. Luxembourg: Publications Office of the European Union.

DOI: http://doi.org/10.2788/52966

Redecker, C. (2017). European Framework for the Digital Competence of Educators: DigCompEdu. Punie, Y. (ed). Luxembourg: Publications Office of the European Union. DOI: http://doi.org/10.2760/159770

Vuorikari, R., Punie, Y., Carretero Gomez, S., \& Van den Brande, G. (2016). DigComp 2.0: The Digital Competence Framework for Citizens. Update Phase 1: The Conceptual Reference Model. Luxembourg Publication Office of the European Union. DOI: http://doi.org/10.2791/11517

\section{REFERENCES}

Havrilova, L., \& Voronova, N. (2017). Tsyfrova kultura yak fenomen suchasnoho informatsiino-komunikatsiinoho pedahohichnoho seredovyshcha [Digital culture as a phenomenon of modern information and communication pedagogical environment]. Zasoby navchalnoi ta naukovo-doslidnoi roboty [Means of educational and research work], 48, 21-34.

DOI: http://doi.org/10.5281/zenodo.1312912 [in Ukrainian]

Henseruk, H. (2019). Tsyfrova kompetentnist yak odna iz profesiino znachushchykh kompetentnostei maibutnikh uchyteliv [Digital competence as one of the professionally significant competencies of future teachers]. Vidkryte osvitnie e-seredovyshche suchasnoho universytetu [Open educational e-environment of modern University], 6, 8-16. Retrieved from: http://nbuv.gov.ua/UJRN/oeeemu_2019_6_4 [in Ukrainian]

Markova, O., Semerikov, S., \& Striuk, A. (2015). Khmarni tekhnolohii navchannia: vytoky [[Cloud learning technologies: origins]. Informatsiini tekhnolohii $i$ zasoby navchannia [Information technologies and teaching aids], 46(2), 29-44. Retrieved from: http://nbuv.gov.ua/UJRN/ITZN_2015_46_2_6. [in Ukrainian]

Morze, N. V., $\quad$ Bazeliuk, O. V., Vorotnikova, I. P., Dementiievska, N. P., Zakhar, O. H., Nanaieva, T. V. . . Chernikova, L. A. (2019). Opys tsyfrovoi kompetentnosti pedahohichnoho pratsivnyka [Description of digital competence of a pedagogical worker]. Vidkryte osvitnie e-seredovyshche suchasnoho universytetu, spetsialnyi vypusk [Open educational e-environment of modern University, special edition]. Retrieved from:

https://elibrary.kubg.edu.ua/id/eprint/27905/1/digital\%20comp\%20teacher\%20Morze.pdf [in Ukrainian]

Ovcharuk, O. (2017). Suchasni vymohy do tsyfrovoi hramotnosti v systemi shkilnoi osvity: na osnovi ramky tsyfrovoi kompetentnosti DigComp 2.0 [Modern requirements for digital literacy in the school education system: based on the digital competence framework DigComp 2.0]. Nova pedahohichna dumka [New pedagogical thought], 4, 32-35. Retrieved from: http://nbuv.gov.ua/UJRN/Npd_2017_4_11 [in Ukrainian] 
Pro vyshchu osvitu [On Higher Education]. № 1556-VII. (2014). Retrieved from: https://zakon.rada.gov.ua/laws/show/1556-VII\#Text [in Ukrainian]

Pro natsionalnu prohramu informatyzatsii [On the National Informatization Program]. № 74/98-VR. (1998). Retrieved from: https://zakon.rada.gov.ua/laws/show/74/98\%D0\%B2\%D1\%80\#Text [in Ukrainian]

Semerikov, S., Striuk, S., \& Moiseienko, N. (2012). Mobilne navchannia: istorykotekhnolohichnyi vymir [Mobile learning: historical and technological dimension]. In O. A. Konoval (ed.). Teoriia $i$ praktyka orhanizatsii samostiinoi roboty studentiv vyshchykh navchalnykh zakladiv [Theory and practice of organizing independent work of students of higher educational institutions] (pp. 188-242). Kryvyi Rih: Knyzhkove vydavnytstvo Kyreievskoho. [in Ukrainian]

Soldatova, G. U., \& Rasskazova, E. I. (2014). Psihologicheskie modeli cifrovoj kompetentnosti rossijskih podrostkov i roditelej [Psychological models of digital competence of Russian adolescents and parents]. Nacional'nyj psihologicheskij zhurnal [National Psychological Journal], 2(14), 27-35. Retrieved from: http://npsyj.ru/articles/detail.php?article=5102 [in Russian]

Soldatova, G. U., Nestik, T. A., Rasskazova, E. I., \& Zotova, E. Ju. (2013). Cifrovaja kompetentnost' podrostkov $i$ roditelej [Digital competence of teenagers and parents]. Retrieved from: https://ifap.ru/library/book536.pdf [in Russian]

Broadband Commission for Sustainable Development (2017). Working Group on Education: Digital skills for life and work. UNESCO; Intel. Retrieved from: https://d-russia.ru/wpcontent/uploads/2017/10/Digital-skills-for-life-and-work_259013e.pdf

Carretero Gomez, S., Vuorikari, R. \& Punie, Y. (2017). DigComp 2.1: The Digital Competence Framework for Citizens with eight proficiency levels and examples of use. Luxembourg: Publications Office of the European Union.

DOI: http://doi.org/10.2760/38842

European Commission. (2019). SELFIE (Self-reflection on Effective Learning by Fostering the use of Innovative Educational technologies). Retrieved from: https://ec.europa.eu/education/schools-go-digital/about-selfie_en

Ferrari, A. (2013). DIGCOMP: A Framework for Developing and Understanding Digital Competence in Europe. Y. Punie \& B. N. Brečko. Luxembourg: Publications Office of the European Union.

DOI: http://doi.org/10.2788/52966

Redecker, C. (2017). European Framework for the Digital Competence of Educators: DigCompEdu. Punie, Y. (ed). Luxembourg: Publications Office of the European Union. DOI: http://doi.org/10.2760/159770

Vuorikari, R., Punie, Y., Carretero Gomez, S., \& Van den Brande, G. (2016). DigComp 2.0: The Digital Competence Framework for Citizens. Update Phase 1: The Conceptual Reference Model. Luxembourg Publication Office of the European Union. DOI: http://doi.org/10.2791/11517 


\section{Доценко Світлана}

доктор педагогічних наук, доцент, завідувач кафедри інформаційних технологій Харківського національного педагогічного університету імені

Г. С. Сковороди

каб. 217, вул. Алчевських, 29, Харків, Україна 61002

Тел. +38(050) 87490500

ORCID ID: 0000-0002-4501-9130

e-mail: svetlana.dotsenko@hnpu.edu.ua

\section{Собченко Тетяна}

кандидат педагогічних наук, доцент, доцент кафедри загальної педагогіки та педагогіки вищої школи Харківського національного педагогічного університету імені Г. С. Сковороди каб. 315-В, вул. Валентинівська, 2, Харків, Україна 61168

Тел. +38(096) 6913370

ORCID ID: 0000-0002-9213-5556

e-mail: sobchenkotetyana79@gmail.com

\section{Svitlana Dotsenko}

Doctor of Pedagogy

Professor at the Information Technology

Department of H. S. Skovoroda Kharkiv

National Pedagogical University

Room 217, 29, Alchevskyh Str, Kharkiv, Ukraine 61002

Тел. +38(050) 874905

ORCID ID: 0000-0002-4501-9130

e-mail: svetlana.dotsenko@hnpu.edu.ua

\section{Sobchenko Tetyana}

Candidate of Pedagogical Sciences, Associate Professor of the Department of General Pedagogy and Higher School Pedagogy H. S. Skovoroda Kharkiv National Pedagogical University Room 315V, 2, Valentynivska Str, Kharkiv, Ukraine 61168

Tel. +380966913370

ORCID ID: 0000-0002-9213-5556

e-mail: sobchenkotetyana79@gmail.com 